\title{
KONDISI OPTIMUM ELEKTROPLATING BAJA KARBON RENDAH MENGGUNAKAN LOGAM SENG (Zn)
}

\author{
Victor Kayadoe $^{1 *}$, Yuli T. Filindity ${ }^{1}$ \\ ${ }^{1}$ Program Studi Pendidikan Matematika, Jurusan MIPA FKIP Unpatti \\ Email: *veky_kayadoe@yahoo.com
}

\begin{abstract}
ABSTRAK. Telah dilakukan penelitian untuk menentukan kondisi optimum pelapisan baja karbon rendah menggunakan logam seng (Zn) dengan metode elektroplating. Penelitian ini menggunakan beberapa variabel yaitu waktu, arus, suhu, dan $\mathrm{pH}$ larutan. Hasil penelitian menunjukan bahwa kondisi optimum untuk menghasilkan kualitas lapisan yang baik adalah pada waktu 10 menit, arus 0,4 ampere, suhu $40^{\circ} \mathrm{C}$ dan $\mathrm{pH}$ 3. Setelah dilakukan uji korosi, baja karbon rendah yang telah dilapisi seng ( $\mathrm{Zn}$ ) mempunyai daya tahan yang tinggi terhadap korosi dibandingkan baja karbon rendah tanpa pelapis. Hal ini disebabkan seng (Zn) sebagai logam pelapis dapat membentuk lapisan oksida yang melindungi baja karbon rendah terhadap kerusakan lebih lanjut.
\end{abstract}

Keywordsi: Kondisi Optimum, elektroplating, baja karbon rendah.

\section{Pendahuluan}

Logam merupakan salah satu material yang mempunyai peranan penting dalam menunjang keberlangsungan hidup manusia. Pemakaiannya terlihat sangat jelas dalam bidang teknik, seperti konstruksi mesin, kendaraan, jembatan, bangunan, pesawat terbang, kapal laut, serta peralatan dapur dan perabot rumah lainnya. Sifat suatu logam sangat menentukan kualitas pemakaiannya. Salah satunya adalah sifat ketahanan terhadap korosi.

Korosi merupakan suatu keadaan atau fenomena yang tak dapat dipungkiri keberlangsungannya pada suatu logam. Keadaan ini dapat diartikan sebagai pengrusakan logam oleh keadaan sekitar yang dapat berupa udara lembab, bahan kimia, air laut, gas, dan sebagainya. Akibat korosi, logam dapat berubah dalam bentuk garamnya, oksida atau hidroksida. Dengan demikian korosi dapat mengurangi daya guna logam tersebut (Trethewey, 1991).

Salah satu cara yang dapat digunakan untuk meningkatkan daya tahan logam terhadap korosi adalah dengan metode pelapisan logam. Pada penerapannya, didapatkan bahwa logam membentuk kulit korosi yang melindungi logam di bawahnya terhadap perusakan lebih lanjut. Ada berbagai cara untuk menerapkan pelapisan logam pada logam lain. Salah satunya adalah elektroplating (penyepuhan).

Elektroplating merupakan metode pelapisan logam dengan menggunakan arus listrik. Metode pelapisan ini memiliki keunikan dan keungulan tersendiri, yakni temperatur operasinya rendah yaitu $30-50^{\circ} \mathrm{C}$, ketebalan logam pelapis mudah dikendalikan, penggunaan pelapis sedikit, serta menghasilkan lapisan dengan ketebalan merata (Bapedal, 1997).

Elektroplating pada prinsipnya merupakan suatu proses pengendapan logam (anoda) pada logam dasar (katoda) melalui proses elektrokimia (Gambar 1), dengan logam yang diendapkan $\left(\mathrm{M}^{0}\right)$ dalam bentuk ion-ion $\left(\mathrm{M}^{\mathrm{n}+}\right)$, melalui media larutan elektrolit oleh arus listrik searah (DC) menuju dan mengendap secara terus-menerus ke permukaan logam dasar (katoda) sampai lapisan menempel kuat (Vlack, 1985). 


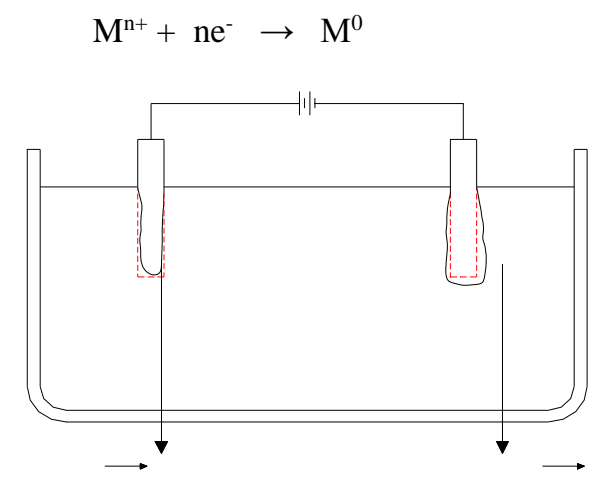

Gambar 1. Proses elektroplating

Pada elektroplating, yang lebih diperlukan bukan mencari berat total logam yang diendapkan pada katoda, melainkan tebal dan distribusi endapan di katoda. Tebal lapisan dari hasil elektroplating dapat ditentukan dengan menggunakan persamaan (Hartomo, 1992):

Tebal Lapisan $=\frac{\text { Berat Lapisan }}{\text { Berat jenis Logam } \mathrm{x} \text { Luas permukaan katoda }}$

Beberapa faktor yang mempengaruhi proses dan hasil elektroplating adalah sifat logam dasar, rapat arus, konsentrasi larutan elektrolit, suhu larutan, pH larutan, pengadukan, dan waktu pelapisan (Companion, 1991; Vlack, 1995; Trethewey, 1991; Avner, 1970).

Walaupun seng lebih anodik daripada besi dalam deret galvanik, produk korosi seperti senyawa-senyawa oksida, hidroksida dan karbonat basa, membentuk selaput pelindung pada permukaan logam yang mengurangi laju korosi seng sampai ke tingkat yang jauh di bawah laju korosi besi (baja). Jadi sebagai pelapis, seng akan panjang umurnya, tetapi sekaligus menjadi tumbal untuk melindungi logam bila lapisan tersebut mengalami retak-retak atau pecah. Ketahanan logam seng terhadap korosi tidak bergantung pada metode pelapisannya, walaupun lapisan yang mengandung $5,8 \%$ besi menurut laporan lebih tahan menghadapi korosi sumuran dibanding seng murni (Trethewey, 1991).

Baja sebagai salah satu logam yang banyak pemakaiannya, tidak terlepas dari masalah korosi. Di Indonesia pembangunan industri baja terus digalakkan dan termasuk kelompok industri strategis yang mempunyai peranan penting dalam pembangunan industri nasional. Korosi merupakan masalah mendasar yang dihadapi industri baja di Indonesia karena lautnya yang luas, lingkungan udara yang lembab serta curah hujan yang tinggi. Dengan demikian penanggulangan secara tepat perlu mendapat perhatian khusus. Untuk maksud ini maka dapat diterapkan pelapisan logam dengan metode elektroplating sebagai salah satu upaya pencegahan korosi baja.

Dari hasil penelitian dengan menggunakan tembaga sebagai pelapis dan baja karbon rendah sebagai logam dasar, diperoleh hasil penelitian dengan kondisi optimum pelapisan yaitu pada arus 0,8 ampere, waktu 75 detik,

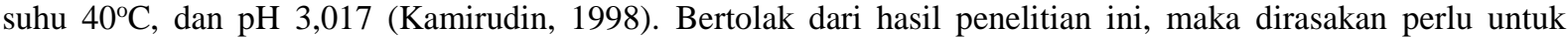
melakukan penelitian serupa dengan menggunakan logam lain sebagai pelapis. Dalam hal ini, digunakan logam seng (Zn) sebagai pelapis karena memiliki potensial reduksi yang lebih rendah dari baja, yang diharapkan lapisan oksida yang terbentuk dapat melindungi baja yang dilapisnya serta mempunyai harga di pasaran yang relatif murah dibandingkan beberapa logam pelapis lainnya, seperti: kadmium $(\mathrm{Cd})$, tembaga $(\mathrm{Cu})$, krom $(\mathrm{Cr})$, dan titanium (Ti) (Hartomo, 1992). Dengan demikian, lewat penelitian ini kiranya dapat memberikan masukan yang cukup berarti bagi perkembangan industri baja di Indonesia.

\section{Metode}

\subsection{Alat dan Bahan}

Alat-alat yang digunakan dalam penelitian ini adalah Seperangkat alat elektroplating (Sumber arus searah (DC), power suplay, amperemeter, hambatan geser, dan kabel penghantar arus), Alat pH meter digital (HANNA), Timbangan analitik (Adam equipment Co. Ltd), Pengaduk magnet, Stop Watch, Penjepit gigi buaya, Hot plate, Mistar geser, Neraca Ohaus 310, Eksikator, Gelas piala $250 \mathrm{~mL}$, Gelas piala $50 \mathrm{~mL}$, Gelas ukur $250 \mathrm{~mL}$, Corong gelas, Termometer, Pengaduk gelas, Kertas amplas No. 320 silicon carbide. 
Bahan-bahan yang digunakan: $\mathrm{NH}_{3}$ (pekat), p.a [E. Merck], $\mathrm{H}_{2} \mathrm{SO}_{4}$ (pekat), p.a [E. Merck], $\mathrm{Na}_{3} \mathrm{PO}_{4}$, p.a [E. Merck], $\mathrm{NaOH}$, p.a [E. Merck], $\mathrm{ZnSO}_{4}$, p.a [E. Merck], NaCl, p.a [E. Merck], Baja karbon rendah (Plat berukuran $3 \times 2 \mathrm{~cm}$, dengan tebal 0,1 cm), Seng (Plat berukuran $3 \times 2 \mathrm{~cm}$ ).

\subsection{Prosedur Kerja}

\section{Tahap Pengerjaan Awal (Bapedal, 1997)}

a. Pembersihan dengan cara mekanik

Pembersihan dengan cara mekanik dilakukan dengan cara penghalusan (buffing). Permukaan plat baja dihaluskan dengan menggunakan kertas amplas No. 320 silicon carbide abrasi paper. Penghalusan permukaan plat baja untuk mendapatkan pelapisan merata pada permukaan plat baja.

b. Pembersihan lemak dan minyak (degreasing)

Larutan pencuci dibuat dari $\mathrm{NaOH}(62,7 \mathrm{~g} / \mathrm{L})$ dan $\mathrm{Na}_{3} \mathrm{PO}_{4}(37,5 \mathrm{~g} / \mathrm{L})$ pada temperatur $70^{\circ} \mathrm{C}$. Baja dicelupkan ke dalam larutan pencuci, guna menghilangkan lemak dan minyak yang menempel pada plat baja.

c. Pembersihan karat (pickling)

Pembersihan karat dilakukan dengan mencelupkan plat baja ke dalam larutan asam sulfat (10\%) pada suhu 40 $-60^{\circ} \mathrm{C}$ selama $5-15$ menit.

d. Pembilasan

Pembilasan plat baja dilakukan dengan cara mencuci dalam wadah berisi air. Pencucian ini dilakukan untuk menghilangkan sisa-sisa bahan pencuci lemak dan pencuci karet yang masih menempel pada permukaan baja.

e. Penimbangan

Plat baja yang akan dilapisi setelah bersih dan kering dimasukkan ke dalam eksikator dan selanjutnya ditimbang dengan menggunakan timbangan neraca analitik.

\section{Tahap Pelapisan (Bapedal, 1997)}

a. Pembuatan larutan elektrolit

Sistem larutan elektrolit yang digunakan adalah $\mathrm{ZnSO}_{4}(225 \mathrm{~g} / \mathrm{L})$, dicampur dengan $\mathrm{H}_{2} \mathrm{SO}_{4}(45 \mathrm{~g} / \mathrm{L})$. Derajat keasaman $(\mathrm{pH})$ larutan diatur menggunakan $\mathrm{H}_{2} \mathrm{SO}_{4}$ (pekat) untuk $\mathrm{pH}$ rendah dan larutan $\mathrm{NH}_{3}$ (pekat) untuk $\mathrm{pH}$ tinggi.

b. Proses elektroplating

Lempeng baja yang akan dilapisi seng dicelupkan ke dalam larutan elektrolit asam sulfat dan seng sulfat, dengan rangkaian alat sebagai berikut:

- Anoda dihubungkan dengan kutub positif sumber listrik

- Katoda dihubungkan dengan kutub negatif sumber listrik

- $\quad$ Anoda dan katoda direndam dalam larutan elektrolit.

Plat seng (anoda) dijepit dengan penjepit buaya, dihubungkan dengan kutub positif sumber arus listrik dan plat baja (katoda) dihubungkan dengan kutub negatif sumber arus listrik, lalu dimasukkan ke dalam sistem larutan elektrolit. Selanjutnya arus diatur sesuai dengan kondisi yang diinginkan, sedangkan variabel lain dibuat tetap. Setelah pengaruh perubahan arus selesai, dilakukan juga pengukuran terhadap pengaruh waktu, suhu dan $\mathrm{pH}$ larutan. Dalam pengukuran setiap variabel, variabel-variabel tersebut diubah-ubah sedangkan variabel yang lain dibuat tetap.

\section{Uji Korosi}

Uji korosi dilakukan dengan mengukur pertambahan berat plat baja tanpa pelapis setelah pembasahan dengan larutan $\mathrm{NaCl} 5 \%$, dibandingkan dengan pertambahan berat plat baja hasil pelapisan setelah pembasahan dengan $\mathrm{NaCl} 5 \%$ dalam selang waktu 24, 48, 72, 96 dan 120 jam.

\section{Hasil Penelitian}

\subsection{Pengaruh Perubahan Waktu}

Pengaruh perubahan waktu pada elektroplating baja karbon rendah menggunakan seng (Zn) dipelajari dengan variasi waktu 5, 10, 15, 20 dan 25 menit, sementara variabel lainnya dibuat tetap, yakni: Arus $0,8 \mathrm{~A}$, suhu $40^{\circ} \mathrm{C}$ dan $\mathrm{pH}=3$. Hasil elektroplatingnya dapat dilihat pada Tabel 1 .

Berdasarkan Tabel 1 dapat dilihat bahwa pada waktu 5 menit, hasil pelapisan sangat tipis dan tidak merata pada permukaan baja. Hal ini disebabkan karena terlalu singkatnya waktu yang digunakan untuk proses perubahan 
kimia dalam proses elektroplating, baik untuk mengendapkan ion logam seng $\left(\mathrm{Zn}^{2+}\right)$ menjadi logamnya maupun untuk pelarutan ion seng $\left(\mathrm{Zn}^{2+}\right)$ ke dalam larutan elektrolit.

Pelapisan pada waktu 10 menit, memperoleh hasil yang baik, dengan berat lapisan 0,0917 gram (tebal lapisan $9,889 \mu \mathrm{m})$. Kualitas lapisan pada waktu 10 menit jika dibandingkan dengan waktu pelapisan yang lain sesuai hasil penelitian ialah merata, melekat baik, halus dan warna abu-abu muda yang cerah seperti warna logam pelapis (seng). Hal ini menunjukkan waktu pelapisan 10 menit memberikan hasil pelapisan optimal dan secara optimum menghasilkan perubahan kimia dalam proses elektroplating, baik untuk menguraikan larutan elektrolit menjadi ion-ion logam $\left(\mathrm{Zn}^{2+}\right)$ untuk diendapkan menjadi logamnya $(\mathrm{Zn})$, maupun untuk pelarutan $\mathrm{Zn}$ (anoda) ke dalam larutan elektrolit.

Hasil pelapisan pada waktu 15, 20, dan 25 menit menunjukkan peningkatan berat lapisan seiring dengan pertambahan waktu. Hal ini sesuai dengan persamaan hukum Faraday bahwa berat logam yang diendapkan sebanding dengan waktu pelapisan. Namun kualitas lapisan yang diperoleh pada variasi waktu ini kuranglah sempurna.

Tabel 1. Hasil Elektroplating dengan Pengaruh Perubahan Waktu terhadap Berat Lapisan

\begin{tabular}{|c|c|c|c|c|c|c|c|}
\hline \multicolumn{2}{|c|}{ Plat Baja } & \multirow[b]{2}{*}{$\begin{array}{l}\text { Waktu } \\
\text { (menit) }\end{array}$} & \multirow{2}{*}{$\begin{array}{l}\text { Rapat } \\
\text { Arus } \\
\left(\mathrm{A} / \mathrm{cm}^{2}\right)\end{array}$} & \multicolumn{2}{|c|}{ Hasil Penimbangan } & \multirow{2}{*}{$\begin{array}{l}\text { Wt }- \text { Wo } \\
(g)\end{array}$} & \multirow{2}{*}{$\begin{array}{l}\text { Tebal } \\
\text { Lapisan } \\
(\mu \mathrm{m})\end{array}$} \\
\hline No & $\begin{array}{l}\text { Luas } \\
\left(\mathrm{cm}^{2}\right)\end{array}$ & & & $\begin{array}{l}\text { Awal (Wo) } \\
(\mathrm{g})\end{array}$ & $\begin{array}{l}\text { Akhir }(\mathrm{Wt}) \\
(\mathrm{g})\end{array}$ & & \\
\hline 1 & 12,792 & 5 & 0,0625 & 4,6893 & 4,7397 & 0,0504 & 5,523 \\
\hline 2 & 13,000 & 10 & 0,0615 & 4,6220 & 4,7137 & 0,0917 & 9,889 \\
\hline 3 & 13,000 & 15 & 0,0615 & 4,6860 & 4,8290 & 0,1430 & 15,421 \\
\hline 4 & 12,876 & 20 & 0,0621 & 4,6038 & 4,7705 & 0,1667 & 18,150 \\
\hline 5 & 12,938 & 25 & 0,0618 & 4,4966 & 4,7246 & 0,2280 & 24,705 \\
\hline
\end{tabular}

Hal ini ditunjukkan dengan permukaan lapisan yang kasar, warna lapisan yang tidak cerah, dan terbentuknya bercak hitam yang kasar pada tepi-tepi baja yang menunjukkan terjadinya oksidasi pada lapisan tersebut. Hasil kurang sempurna ini disebabkan waktu pelapisan terlalu lama dan juga menurunnya konsentrasi ion-ion logam $\left(\mathrm{Zn}^{2+}\right)$ dalam sistem elektrolit seiring berjalannya waktu.

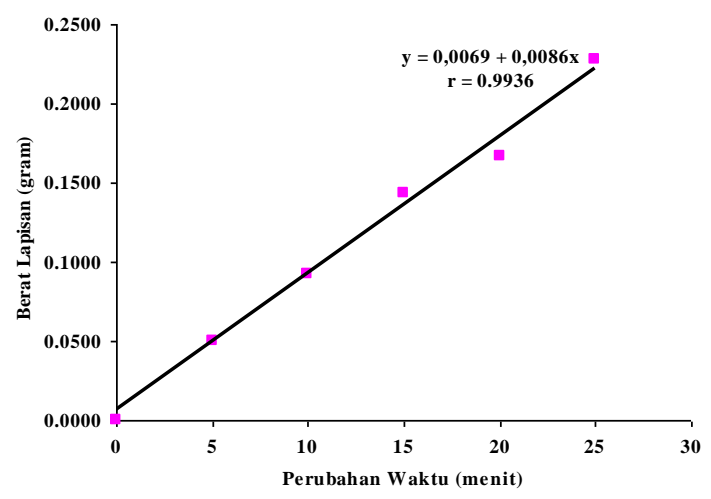

Gambar 2. Grafik Pengaruh Perubahan Waktu terhadap Berat Lapisan

Hasil analisa korelasi menggunakan program excel yang ditunjukkan pada Gambar 2, diperoleh nilai koefisien korelasi (r) sebesar 0,9936. Karena nilai $\mathrm{r}$ analisa korelasi hasil penelitian lebih besar dari nilai $\mathrm{r}$ pada tabel $(\mathrm{P}=0,05 ; \mathrm{DB}=3)$, yakni 0,878 , maka ada korelasi nyata antara perubahan waktu terhadap berat lapisan. Korelasi nyata menunjukkan bahwa berat lapisan yang terbentuk akan meningkat dengan

kenaikan waktu pelapisan dalam proses elektroplating. Grafik hubungan antara perubahan waktu terhadap berat lapisan ditunjukkan pada Gambar 2.

\subsection{Pengaruh Perubahan Arus}

Pada elektroplating baja karbon rendah menggunakan seng ( $\mathrm{Zn}$ ) dengan variasi arus, variabel lainnya dibuat tetap, yaitu waktu 10 menit, suhu $40^{\circ} \mathrm{C}$, dan $\mathrm{pH}=3,0$. Hasil elektroplatingnya ditunjukkan pada Tabel 2. 
Berdasarkan Tabel 2, dapat dilihat bahwa arus pelapisan 0,2 A memberikan hasil yang kurang sempurna. Lapisan seng $(\mathrm{Zn})$ yang terbentuk pada permukaan baja tidak merata dan sangat tipis. Hal ini disebabkan arus tersebut terlalu rendah untuk menghasilkan perubahan kimia dalam proses elektroplating, sehingga penguraian larutan elektrolit menjadi ion-ion logam yang akan diendapkan pada baja kurang optimal. Arus tersebut juga berkurang akibat tahanan elektrolit dan reaksi-reaksi samping seperti reaksi pembentukan gas di sekitar elektroda. Reaksi pengendapan logam seng (Zn) pada baja karbon rendah (katoda):

$$
\mathrm{ZnSO}_{4(\mathrm{aq})} \rightarrow \mathrm{Zn}^{2+}{ }_{(\mathrm{aq})}+\mathrm{SO}_{4}{ }_{(\mathrm{aq})}^{2-}
$$

Katoda $: \mathrm{Zn}^{2+}{ }_{(\mathrm{aq})}+2 \mathrm{e} \rightarrow \mathrm{Zn}_{(\mathrm{s})}$

Anoda $: \mathrm{H}_{2} \mathrm{O}_{(\mathrm{l})}+\mathrm{SO}_{4}{ }^{2-}{ }_{(\mathrm{aq})} \rightarrow 1 / 2 \mathrm{O}_{2(\mathrm{~g})}+\mathrm{H}_{2} \mathrm{SO}_{4(\mathrm{aq})}+2 \mathrm{e}$

$$
\mathrm{ZnSO}_{4(\mathrm{aq})}+\mathrm{H}_{2} \mathrm{O}_{(\mathrm{l})} \rightarrow \mathrm{Zn}_{(\mathrm{s})}+1 / 2 \mathrm{O}_{2(\mathrm{~g})}+\mathrm{H}_{2} \mathrm{SO}_{4(\mathrm{aq})}
$$

Pada arus pelapisan 0,4 A memberikan hasil pelapisan yang baik, di mana lapisan seng (Zn) yang terbentuk tebal, merata, serta permukaannya halus dengan warna abu-abu muda yang cerah. Pada arus ini (rapat arus 0,0305 $\mathrm{A} / \mathrm{cm}^{2}$ ) dapat menghasilkan perubahan kimia secara optimal dalam proses elektroplating baik dalam mengatasi tahanan elektrolit dan reaksi-reaksi samping, maupun untuk menguraikan $\mathrm{ZnSO}_{4}$ menjadi ion-ion logam seng $\left(\mathrm{Zn}^{2+}\right)$ untuk kemudian diendapkan menjadi logam seng $(\mathrm{Zn})$ pada permukaan baja dan arus tersebut optimal juga dalam melarutkan anoda (seng) ke dalam larutan elektrolit. Selain itu, berdasarkan hasil perhitungan efisiensi arus (Lampiran 10) diperoleh bahwa arus 0,4 A memiliki efisiensi yang lebih tinggi dibandingkan arus lainnya, yaitu 85,36\%. Artinya pada arus 0,4 A berat logam seng ( $\mathrm{Zn}$ ) yang diendapkan berdasarkan hasil penelitian hampir sama dengan berat logam seng ( $\mathrm{Zn}$ ) yang dhitung dengan menggunakan persamaan Hukum Faraday.

Pada arus pelapisan 0,6, 0,8, 1,0 A, berat lapisan dan tebal lapisan yang diperoleh relatif meningkat. Hasil pelapisan yang diperoleh kurang sempurna seperti agak kasar dan warnanya tidak cerah. Hal ini terjadi karena penggunaan arus yang tinggi menyebabkan distribusi ion logam seng $\left(\mathrm{Zn}^{2+}\right)$ semakin cepat, sehingga posisi deposit tidak stabil. Dengan demikian dapat menghambat epitaksi, yaitu suatu kondisi dimana struktur kisi logam dasar dan pelapis serupa (Hartomo, 1992).

Pada arus pelapisan 0,6, 0,8, 1,0 A, berat lapisan dan tebal lapisan yang diperoleh relatif meningkat. Hasil pelapisan yang diperoleh kurang sempurna seperti agak kasar dan warnanya tidak cerah. Hal ini terjadi karena penggunaan arus yang tinggi menyebabkan distribusi ion logam seng $\left(\mathrm{Zn}^{2+}\right)$ semakin cepat, sehingga posisi deposit tidak stabil. Dengan demikian dapat menghambat epitaksi, yaitu suatu kondisi dimana struktur kisi logam dasar dan pelapis serupa (Hartomo, 1992).

Pada arus pelapisan 0,6, 0,8, 1,0 A, berat lapisan dan tebal lapisan yang diperoleh relatif meningkat. Hasil pelapisan yang diperoleh kurang sempurna seperti agak kasar dan warnanya tidak cerah. Hal ini terjadi karena penggunaan arus yang tinggi menyebabkan distribusi ion logam seng $\left(\mathrm{Zn}^{2+}\right)$ semakin cepat, sehingga posisi

Pada arus pelapisan 0,6, 0,8, 1,0 A, berat lapisan dan tebal lapisan yang diperoleh relatif meningkat. Hasil pelapisan yang diperoleh kurang sempurna seperti agak kasar dan warnanya tidak cerah. Hal ini terjadi karena penggunaan arus yang tinggi menyebabkan distribusi ion logam seng $\left(\mathrm{Zn}^{2+}\right)$ semakin cepat, sehingga posisi deposit tidak stabil. Dengan demikian dapat menghambat epitaksi, yaitu suatu kondisi dimana struktur kisi logam dasar dan pelapis serupa (Hartomo, 1992).

Pada arus pelapisan 0,6, 0,8, 1,0 A, berat lapisan dan tebal lapisan yang diperoleh relatif meningkat. Hasil pelapisan yang diperoleh kurang sempurna seperti agak kasar dan warnanya tidak cerah. Hal ini terjadi karena penggunaan arus yang tinggi menyebabkan distribusi ion logam seng $\left(\mathrm{Zn}^{2+}\right)$ semakin cepat, sehingga posisi deposit tidak stabil. Dengan demikian dapat menghambat epitaksi, yaitu suatu kondisi dimana struktur kisi logam dasar dan pelapis serupa (Hartomo, 1992).

Hasil elektroplating Zn pada baja karbon rendah dengan pengaruh perubahan arus ini, cenderung mengikuti hukum Faraday yang pertama, yakni: "Jumlah berat logam yang diendapkan pada katoda selama elektroplating sebanding dengan arus listrik yang melalui larutan" (Achmad 2001). Hal ini menunjukkan adanya kesesuaian antara arus dengan konsentrasi, suhu, waktu dan $\mathrm{pH}$ yang digunakan.

Hasil analisa korelasi menggunakan program excel, diperoleh nilai koefisien korelasi (r) sebesar 0,9959. Karena nilai $r$ hasil analisa korelasi lebih besar dari nilai $r$ pada tabel $(\mathrm{P}=0,05$; $\mathrm{DB}=3$ ), yakni 0,878 , maka ada korelasi nyata antara perubahan arus terhadap berat lapisan yang terbentuk. Korelasi nyata ini menunjukkan bahwa berat lapisan yang terbentuk akan meningkat dengan kenaikan arus pelapisan dalam elektroplating. 
Tabel 2. Hasil Elektroplating dengan Pengaruh Perubahan Arus

\begin{tabular}{|c|c|c|c|c|c|c|c|}
\hline Plat Baja & \multicolumn{2}{|c|}{$\begin{array}{l}\text { Arus } \\
\text { (Ampere) }\end{array}$} & \multicolumn{2}{|l|}{$\begin{array}{l}\text { Rapat } \\
\text { Arus } \\
\left(\mathrm{A} / \mathrm{cm}^{2}\right)\end{array}$} & & \multirow[t]{2}{*}{$\begin{array}{l}\text { Wt - Wo } \\
(\mathrm{g})\end{array}$} & \multirow[t]{2}{*}{$\begin{array}{l}\text { Tebal } \\
\text { Lapisan } \\
(\mu \mathrm{m})\end{array}$} \\
\hline $\begin{array}{l}\text { Luas } \\
\left(\mathrm{cm}^{2}\right)\end{array}$ & & & $\begin{array}{l}\text { Awal (Wo) } \\
(\mathrm{g})\end{array}$ & $\begin{array}{l}\text { Akhir (Wt) } \\
\text { (g) }\end{array}$ & & & \\
\hline 12,342 & 0,2 & 0,0162 & 4,2549 & 4,2839 & 0,0290 & & \\
\hline 13,094 & 0,4 & 0,0305 & 4,6043 & 4,6737 & 0,0694 & & \\
\hline 13,740 & 0,6 & 0,0437 & 4,7828 & 4,8727 & 0,0899 & & \\
\hline 13,224 & 0,8 & 0,0605 & 4,4127 & 4,5625 & 0,1198 & & \\
\hline 12,938 & 1,0 & 0,0773 & 4,6325 & 4,7826 & 0,1501 & & \\
\hline
\end{tabular}

Grafik hubungan antara perubahan Arus terhadap berat lapisan dapat dilihat pada Gambar 3.

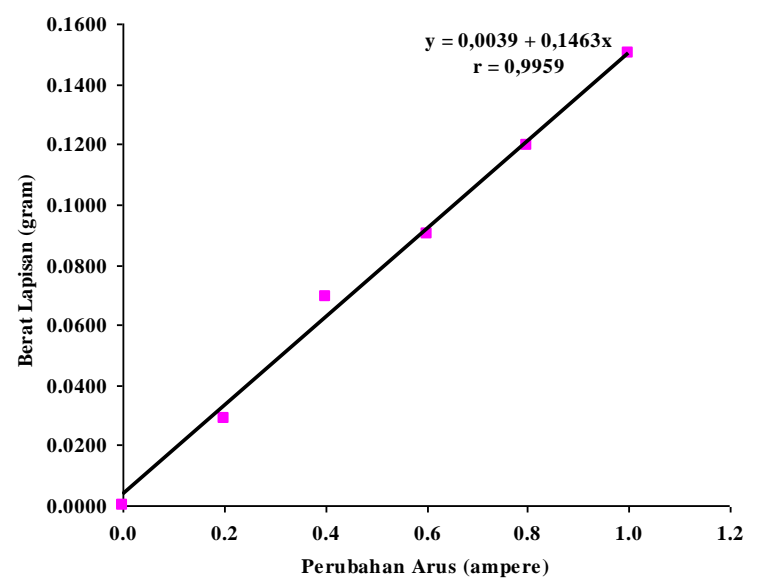

Gambar 3. Grafik Pengaruh Perubahan Arus terhadap Berat Lapisan

\subsection{Pengaruh Perubahan Suhu}

Pada elektroplating baja karbon rendah menggunakan seng $(\mathrm{Zn})$ dengan variabel tetap, yaitu waktu 10 menit, arus $=0,4$ ampere, dan $\mathrm{pH}=3,0$, variabel suhu dibuat tidak tetap untuk melihat pengaruh perubahan suhu terhadap berat lapisan. Hasil elektroplatingnya dapat dilihat pada Tabel 3.

Berdasarkan Tabel 3, terlihat bahwa pada pelapisan dengan suhu larutan $30^{\circ} \mathrm{C}$ dan $35^{\circ} \mathrm{C}$ diperoleh hasil kurang sempurna. Secara keseluruhan peningkatan ketebalan pada setiap variabel suhu tidak menunjukkan peningkatan yang besar, namun pada suhu ini ketebalan yang dihasilkan tidak atau kurang merata walaupun menghasilkan warna yang cerah. Hal ini disebabkan karena rendahnya suhu.

Tabel 3. Hasil Elektroplating dengan Pengaruh Perubahan Suhu terhadap Berat Lapisan

\begin{tabular}{|c|c|c|c|c|c|c|c|}
\hline \multicolumn{2}{|c|}{ Plat Baja } & \multirow[b]{2}{*}{$\begin{array}{l}\text { Suhu } \\
\left({ }^{\circ} \mathrm{C}\right)\end{array}$} & \multirow{2}{*}{$\begin{array}{l}\text { Rapat } \\
\text { Arus } \\
\left(\mathrm{A} / \mathrm{cm}^{2}\right)\end{array}$} & \multicolumn{2}{|c|}{ Hasil Penimbangan } & \multirow[b]{2}{*}{$\begin{array}{l}\text { Wt - Wo } \\
(\mathrm{g})\end{array}$} & \multirow{2}{*}{$\begin{array}{l}\text { Tebal } \\
\text { Lapisan } \\
(\mu \mathrm{m})\end{array}$} \\
\hline No & $\begin{array}{l}\text { Luas } \\
\left(\mathrm{cm}^{2}\right)\end{array}$ & & & $\begin{array}{l}\text { Awal (Wo) } \\
(\mathrm{g})\end{array}$ & $\begin{array}{l}\text { Akhir }(\mathrm{Wt}) \\
(\mathrm{g})\end{array}$ & & \\
\hline 1 & 12,668 & 30 & 0,0316 & 4,6808 & 4,7458 & 0,0650 & 7,193 \\
\hline 2 & 12,546 & 35 & 0,0319 & 4,3512 & 4,4170 & 0,0658 & 7,352 \\
\hline 3 & 12,444 & 40 & 0,0321 & 4,0603 & 4,1267 & 0,0664 & 7,480 \\
\hline 4 & 12,832 & 45 & 0,0312 & 4,4299 & 4,4970 & 0,0671 & 7,330 \\
\hline 5 & 13,532 & 50 & 0,0296 & 4,5385 & 4,6063 & 0,0678 & 7,024 \\
\hline
\end{tabular}

Pada pelapisan dengan suhu $40^{\circ} \mathrm{C}$ hasil pelapisan yang diperoleh baik, permukaan halus, lapisan merata dan warna abu-abu muda yang cerah. Pada suhu $40^{\circ} \mathrm{C}$ ini hasil pelapisan optimal dengan berat lapisan 0,0664 gram 
(tebal lapisan 7,480 $\mu \mathrm{m}$ ) dan rapat arus $0,0321 \mathrm{~A} / \mathrm{cm}^{2}$. Hal ini menunjukkan bahwa pelapisan dengan suhu larutan $40^{\circ} \mathrm{C}$, telah mampu menghasilkan pelapisan yang optimal dalam proses elektroplating. Pada kondisi tersebut terjadi peningkatan kecepatan penguraian ion-ion logam dalam larutan, kecepatan difusi ion-ion logam ke katoda (baja) dan pembentukan ion logam seng $\left(\mathrm{Zn}^{2+}\right)$ secara optimum.

Pada pelapisan dengan suhu larutan $45^{\circ} \mathrm{C}$ dan $50^{\circ} \mathrm{C}$, berat atau tebal lapisan yang dihasilkan menunjukkan peningkatan yang tidak terlalu besar namun permukaan lapisan kasar, warnanya kurang cerah serta lapisan tidak melekat dengan baik. Hal ini disebabkan karena kenaikan suhu larutan dalam elektroplating dapat meningkatkan kecepatan penguraian senyawa dalam larutan, kecepatan difusi ion-ion logam ke arah katoda dan kecepatan pembentukan endapan pada permukaan katoda sehingga lapisan yang dihasilkan menjadi kasar. Lapisan tidak melekat baik pada suhu yang tinggi karena daya hantar listrik pada logam menurun dengan meningkatnya suhu. Menurut Companion (1991), gelombang elektron sebagai pembawa arus akan bertabrakan dengan atom yang bergetar. Di mana, Getaran kisi meningkat dengan meningkatnya suhu. Dengan demikian meningkatkan gangguan dan bauran gelombang elektron pembawa. Akibatnya logam pelapis tidak melekat baik pada logam dasar atau kekuatan ikatan antara logam dasar dan logam pelapis berkurang.

Hasil analisa korelasi menggunakan program excel, diperoleh nilai koefisien korelasi (r) sebesar 0,9993. Karena nilai hasil analisa korelasi lebih besar dari $\mathrm{r}$ tabel $(\mathrm{P}=0,05$; $\mathrm{DB}=3)$, yakni 0,878, maka ada korelasi nyata antara perubahan suhu terhadap berat lapisan. Artinya dengan meningkatnya suhu larutan dalam proses elektroplating maka berat lapisan yang terbentuk akan semakin meningkat. Grafik hubungan antara perubahan suhu terhadap berat lapisan dapat dilihat pada Gambar 4.

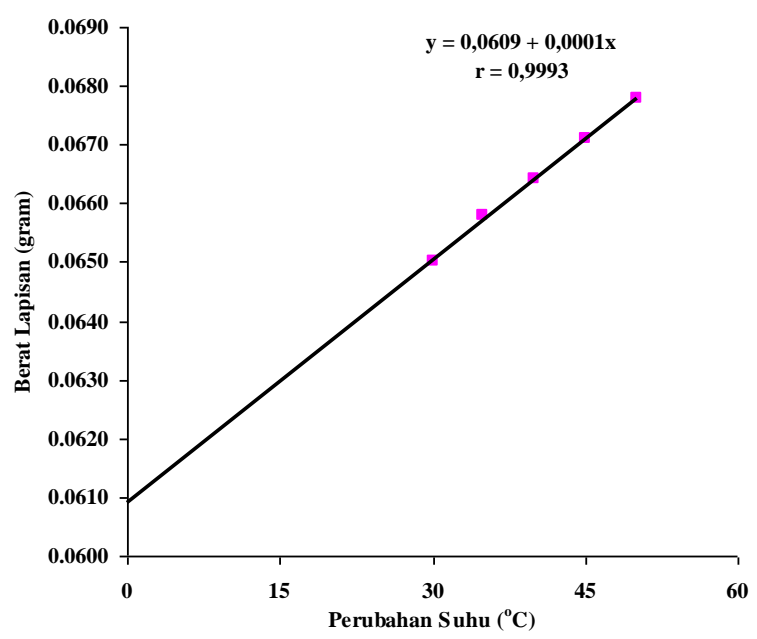

Gambar 4. Grafik Pengaruh PerubahanSuhu terhadap Berat Lapisan

\subsection{Pengaruh Perubahan $\mathrm{pH}$}

Pada elektroplating baja karbon rendah menggunakan logam seng $(\mathrm{Zn})$ dengan pengaruh perubahan $\mathrm{pH}$ larutan, variabel lain dibuat tetap yaitu arus 0,4 ampere, waktu 10 menit dan suhu $40^{\circ} \mathrm{C}$, terlihat pada $\mathrm{pH}=2$. Hasil elektroplatingnya dapat dilihat pada Tabel 4.

Hasil penelitian menunjukkan bahwa pada $\mathrm{pH}=2$, kualitas hasil pelapisan kurang sempurna yaitu tipis dan kurang merata. Hal ini disebabkan karena penambahan $\mathrm{H}_{2} \mathrm{SO}_{4}$ pekat, yang digunakan untuk menurunkan $\mathrm{pH}$ larutan. $\mathrm{H}_{2} \mathrm{SO}_{4}$ yang ditambahkan dalam larutan dapat menyebabkan pelepasan hidrogen pada sistem elektrolit sehingga lapisan pecah-pecah, tidak teratur dan tidak melekat dengan baik.

Pada pelapisan dengan $\mathrm{pH}=3$, diperoleh hasil pelapisan yang baik, seperti permukaan halus, melekat dengan baik, lapisan merata dan warna ungu muda yang cerah. Pada $\mathrm{pH} 3$ ini hasil pelapisan optimal dengan berat lapisan 0,0631 gram dan tebal lapisan $6,849 \mu \mathrm{m}$, serta rapat arus $0,0310 \mathrm{~A} / \mathrm{cm}^{2}$.

Tabel 4. Hasil Elektroplating dengan Pengaruh Perubahan $\mathrm{pH}$ terhadap Berat Lapisan

\begin{tabular}{|c|c|c|c|c|c|c|c|}
\hline \multicolumn{2}{|c|}{ Plat Baja } & \multirow[b]{2}{*}{$\mathrm{pH}$} & \multirow{2}{*}{$\begin{array}{l}\text { Rapat } \\
\text { Arus } \\
\left(\mathrm{A} / \mathrm{cm}^{2}\right)\end{array}$} & \multicolumn{2}{|c|}{ Hasil Penimbangan } & \multirow{2}{*}{$\begin{array}{l}\text { Wt }-\mathrm{Wo}_{\mathrm{o}} \\
(\mathrm{g})\end{array}$} & \multirow{2}{*}{$\begin{array}{l}\text { Tebal } \\
\text { Lapisan } \\
(\mu \mathrm{m})\end{array}$} \\
\hline No & $\begin{array}{l}\text { Luas } \\
\left(\mathrm{cm}^{2}\right)\end{array}$ & & & $\begin{array}{l}\text { Awal (Wo) } \\
\text { (g) }\end{array}$ & $\begin{array}{l}\text { Akhir (Wt) } \\
(\mathrm{g})\end{array}$ & & \\
\hline
\end{tabular}




\begin{tabular}{cccccccc}
\hline 1 & 12,792 & 2 & 0,0312 & 4,6793 & 4,7301 & 0,0508 & 5,550 \\
\hline 2 & 13,000 & 3 & 0,0310 & 4,3165 & 4,3796 & 0,0631 & 6,849 \\
\hline 3 & 13,000 & 4 & 0,0324 & 4,1802 & 4,2441 & 0,0639 & 7,258 \\
\hline 4 & 12,876 & 5 & 0,0313 & 4,3042 & 4,3707 & 0,0665 & 7,296 \\
\hline 5 & 12,938 & 6 & 0,0312 & 4,5721 & 4,6408 & 0,0687 & 7,528 \\
\hline
\end{tabular}

$\mathrm{pH}$ tersebut merupakan kondisi $\mathrm{pH}$ optimum karena dapat meningkatkan perubahan kimia sistem elektrolit sehingga ion-ion logam dalam sistem elektrolit dapat diendapkan menjadi logamnya pada permukaan katoda.

Pada pelapisan dengan $\mathrm{pH}$ larutan 4, 5, dan 6, berat lapisan yang terbentuk tidak menunjukkan peningkatan yang berarti serta hasil pelapisannya tidak baik, yakni kasar, tidak merata dan warnanya hitam akibat korosi. Hal ini terjadi karena penambahan amonia untuk menaikkan $\mathrm{pH}$ antara ion-ion logam seng $\left(\mathrm{Zn}^{2+}\right)$ yang ada dalam larutan membentuk kompleks dengan amonia sehingga ion-ion logam dalam sistem elektrolit berkurang dan yang tereduksi hanyalah reduksi ion hidrogen $\left(\mathrm{H}^{+}\right)$. Akibatnya terjadi pelepasan gas hidrogen dari sistem elektrolit.

$2 \mathrm{H}^{+}+2 \mathrm{e}^{-} \rightarrow \mathrm{H}_{2}$

Penambahan $\mathrm{NH}_{3}$ pada sistem elektrolit dapat menghasilkan endapan putih (Achmad, 2001). $2 \mathrm{Zn}^{2+}+\mathrm{SO}_{4}{ }^{2-}+\mathrm{NH}_{3}+\mathrm{H}_{2} \mathrm{O} \rightarrow \mathrm{Zn}(\mathrm{OH})_{2} \cdot \mathrm{ZnSO}_{4} \downarrow+2 \mathrm{NH}_{4}{ }^{+}$

$\mathrm{Zn}(\mathrm{OH})_{2} \cdot \mathrm{ZnSO}_{4}$ ini akan larut bila ditambah amonia berulang-ulang untuk menaikkan $\mathrm{pH}$ larutan membentuk ion kompleks tetraaminseng (II):

$\mathrm{Zn}(\mathrm{OH})_{2} \cdot \mathrm{ZnSO}_{4} \downarrow+\mathrm{NH}_{3} \rightarrow 2\left[\mathrm{Zn}\left(\mathrm{NH}_{3}\right)_{4}\right]^{2+}+\mathrm{SO}_{4}{ }^{2-}+2 \mathrm{OH}^{-}$

Produksi ion $\mathrm{OH}$ - ini akan menghambat proses melarutnya logam seng ( $\mathrm{Zn}$ ), karena ion-ion bermuatan negatif (anion) cenderung mengalir ke permukaan anoda untuk dioksidasi (Hartomo, 1992). Akibatnya tidak terjadi peningkatan berat lapisan yang berarti serta lapisan pada katoda tersebut menghasilkan warna gelap. Hal ini menunjukkan seng ( $\mathrm{Zn}$ ) sedikit terlapiskan pada baja dan yang lebih banyak terlapiskan (direduksi) pada baja adalah hidrogen.

Hasil analisa korelasi menggunakan program excel, diperoleh koefisien korelasi (r) sebesar 0,8909. Nilai r hasil analisa korelasi lebih besar dari nilai $\mathrm{r}$ tabel $(\mathrm{P}=0,05 ; \mathrm{DB}=3)$, yakni 0,878 , menunjukkan adanya korelasi nyata antara perubahan $\mathrm{pH}$ larutan dengan berat lapisan. Namun, jika dilihat dari selisihnya yang sangat kecil, maka dapat dikatakan bahwa pengaruh perubahan $\mathrm{pH}$ larutan kecil terhadap peningkatan berat lapisan. Grafik hubungan antara perubahan $\mathrm{pH}$ terhadap berat lapisan dapat dilihat pada Gambar 5.

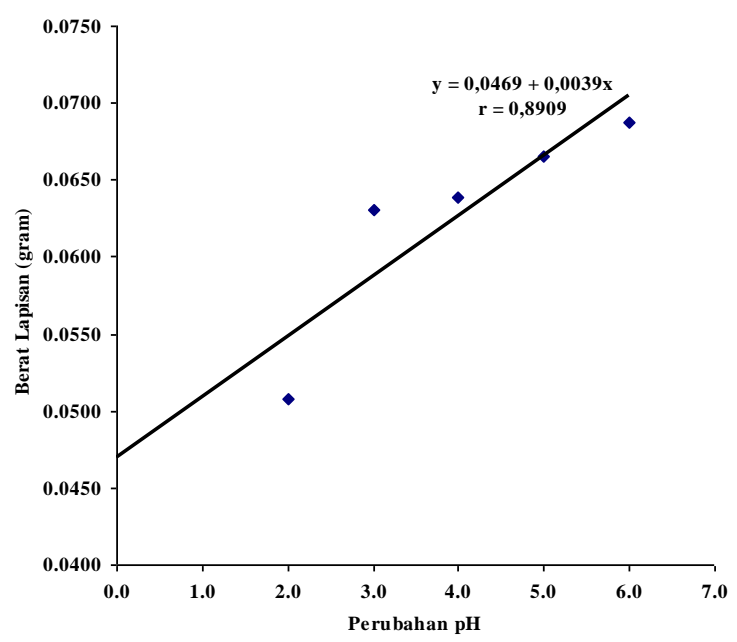

Gambar 5. Grafik Pengaruh Perubahan Waktu terhadap Berat Lapisan

\subsection{Uji Korosi}

Setelah diperoleh kondisi optimum proses elektroplating seng (Zn) pada baja karbon rendah, yakni waktu 10 menit, arus 0,4 ampere, suhu $40^{\circ} \mathrm{C}$, dan $\mathrm{pH}=3,0$. Selanjutnya dilakukan uji korosi terhadap plat hasil pelapisan seng (Zn). Plat yang diuji korosikan yaitu plat yang dilapisi seng (Zn) pada kondisi optimum tersebut. Kemudian dibandingkan dengan plat baja tanpa pelapis. Uji korosi ini bertujuan untuk mengetahui daya tahan baja lapis seng (Zn) dengan plat baja tanpa pelapis. 
Pengamatan pembentukan karat dan pertambahan berat plat ini dilakukan setelah waktu 24, 48, 72, 96, dan 120 jam dari saat pencelupan masing-masing plat dalam larutan $\mathrm{NaCl} 5 \%$. Pertambahan berat plat baja dengan pelapis dan plat baja tanpa pelapis untuk uji korosi secara kuantitatif sedangkan kecepatan pembentukan karat merupakan hasil uji korosi secara kualitatif. Hasil Uji korosi tersebut dapat dilihat pada Tabel 5.

Hasil uji korosi setelah waktu 24 jam, plat baja tanpa pelapis dengan cepat mengalami korosi. Hal ini terlihat dengan adanya noda-noda merah kehitaman yang merupakan lapisan oksida, berat lapisan oksidanya 0,0027 gram dengan persentase kenaikan berat 0,090\%. Sedangkan plat baja hasil pelapisan seng (Zn) belum memperlihatkan bercak-bercak merah (lapisan oksida) meskipun terjadi pertambahan berat plat yang kecil 0,0020 $(0,070 \%)$.

Setelah 48 jam, plat baja tanpa pelapis beratnya bertambah dengan lapisan oksida pada permukaan baja $\left(\mathrm{Fe}_{2} \mathrm{O}_{3}\right)$ yaitu 0,0036 gram $(0,115 \%)$. Sedangkan pada permukaan baja dengan pelapis seng $(\mathrm{Zn})$ mulai terlihat noda-noda hitam dengan pertambahan berat 0,0025 gram $(0,084 \%)$.

Reaksi pembentukan karat $\left(\mathrm{Fe}_{2} \mathrm{O}_{3}\right)$ oleh ion $\mathrm{Cl}^{-}$(Plindek, V.R. 1977) :

$$
\mathrm{Fe}^{2+}+2 \mathrm{H}_{2} \mathrm{O}+2 \mathrm{Cl}^{-} \rightarrow \mathrm{Fe}(\mathrm{OH})_{2}+2 \mathrm{HCl}
$$

Jika kontak dengan oksigen akan menghasilkan $\mathrm{Fe}(\mathrm{OH})_{3}$ :

$4 \mathrm{Fe}(\mathrm{OH})_{2}+\mathrm{O}_{2}+2 \mathrm{H}_{2} \mathrm{O} \rightarrow 4 \mathrm{Fe}(\mathrm{OH})_{3}$

Dehidrolisis senyawa tersebut mengarah pada proses pembentukan korosi yang sering ditemui pada permukaan baja :

$$
2 \mathrm{Fe}(\mathrm{OH})_{3} \rightarrow \mathrm{Fe}_{2} \mathrm{O}_{3}+3 \mathrm{H}_{2} \mathrm{O}
$$

Selama 72 jam di dalam larutan $\mathrm{NaCl}$ pada udara terbuka, permukaan plat baja tanpa pelapis hampir seluruh permukaannya terkorosi dengan pertambahan berat 0,0066 gram $(0,231 \%)$. Sedangkan plat baja dengan pelapis seng (Zn) tidak menunjukkan pertambahan noda-noda hitam yang banyak. Hal ini karena pada baja yang dilapisi seng $(\mathrm{Zn})$ membentuk lapisan oksida yang dapat mencegah efek-efek korosi di udara terbuka, beratnya 0,0044 $(0,138 \%)$.

\begin{tabular}{|c|c|c|c|c|c|c|c|c|c|}
\hline \multirow{4}{*}{ No } & \multirow{4}{*}{$\begin{array}{l}\text { Waktu } \\
\text { Korosi } \\
\text { (Jam) }\end{array}$} & \multicolumn{4}{|c|}{ Berat Plat Baja } & \multirow{2}{*}{\multicolumn{2}{|c|}{$\begin{array}{l}\text { Pertambahan } \\
\text { Berat }(\mathrm{g})\end{array}$}} & \multirow{2}{*}{\multicolumn{2}{|c|}{$\begin{array}{l}\text { Persentase } \\
\text { Pertambahan } \\
(\%) \\
\end{array}$}} \\
\hline & & \multicolumn{2}{|l|}{ Wo $(g)$} & \multicolumn{2}{|l|}{$\mathrm{Wt}(\mathrm{g})$} & & & & \\
\hline & & Tanpa & dengan & Tanpa & dengan & Tanpa & dengan & Tanpa & dengan \\
\hline & & Pelapis & Pelapis & Pelapis & Pelapis & Pelapis & Pelapis & Pelapis & Pelapis \\
\hline 1. & 0 & 2,9883 & 2,8502 & - & - & - & - & - & - \\
\hline 2. & 24 & 2,9883 & 2,8502 & 2,9910 & 2,8522 & 0,0027 & 0,0020 & 0,090 & 0,070 \\
\hline 3. & 48 & 3,1169 & 2,9892 & 3,1205 & 2,9917 & 0,0036 & 0,0025 & 0,115 & 0,084 \\
\hline 4. & 72 & 2,8608 & 3,1926 & 2,8674 & 3,1970 & 0,0066 & 0,0044 & 0,231 & 0,138 \\
\hline 5. & 96 & 2,6698 & 2,9626 & 2,6839 & 2,9675 & 0,0141 & 0,0049 & 0,528 & 0,165 \\
\hline 6. & 120 & 2,7180 & 2,8986 & 2,7580 & 2,9047 & 0,0400 & 0,0061 & 1,472 & 0,210 \\
\hline
\end{tabular}

Tabel 5. Hasil Uji Korosi pada Plat Baja Tanpa Pelapis dan Plat Baja yang Telah Dilapisi Seng (Zn)

Dari Grafik pada Gambar 6, terlihat bahwa pada waktu di atas 72 jam (3 hari) laju korosi baja tanpa pelapis menjadi meningkat (berlangsung secara eksponen), sedangkan pada baja karbon dengan pelapis seng ( $\mathrm{Zn}$ ) laju korosinya naik secara konstan (linear). Hal ini menunjukkan bahwa di atas waktu 72 jam proses korosi pada baja karbon rendah akan semakin cepat yang berakibat fatal bagi kerusakan baja karbon rendah.

Permukaan baja tanpa pelapis telah tertutupi lapisan oksida setelah 96 jam dengan berat $0,0141(0,528 \%)$, sedangkan plat baja dengan pelapis seng $(\mathrm{Zn})$ beratnya $0,0049(0,165 \%)$ dengan permukaan relatif baik walaupun ada sedikit noda-noda hitam pada permukaan tersebut. Selama 120 jam, plat baja tanpa pelapis mengalami pertambahan berat yang terus meningkat, yaitu 0,0400 gram $(1,472 \%)$ sedangkan plat baja dengan pelapis seng (Zn) beratnya bertambah 0,0061 gram $(0,210 \%)$.

Hubungan antara persentase pertambahan berat plat baja terhadap waktu (lama korosi), untuk plat baja tanpa pelapis dan plat baja dengan pelapis seng ( $\mathrm{Zn}$ ) ditunjukkan pada Gambar 4.5.

Dengan demikian, laju pertambahan berat baja tanpa pelapis akibat korosi akan semakin meningkat seiring dengan berjalannya waktu. Namun, setelah dilapisi seng (Zn), laju pertambahan berat baja akibat korosi tidak menunjukkan peningkatan yang berarti. 


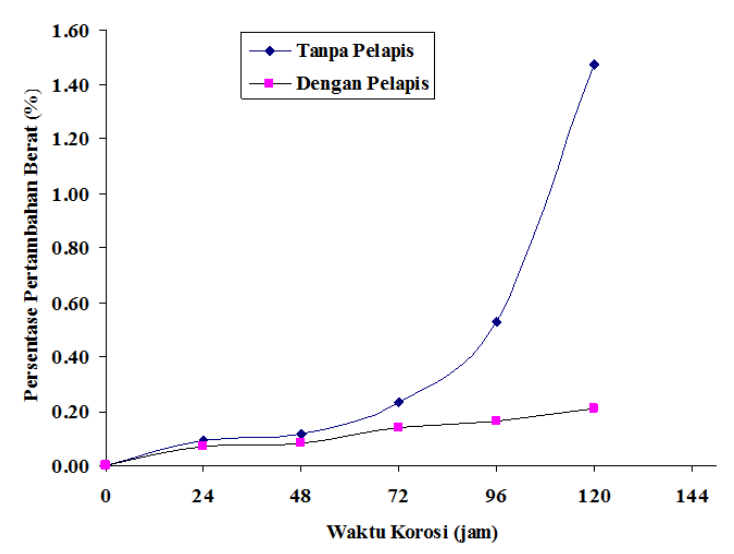

Gambar 6. Grafik Persentase Pertambahan Berat terhadap Waktu Korosi

\section{Kesimpulan}

1. Kondisi Optimum proses pelapisan baja karbon rendah menggunakan seng (Zn) dengan metode elektroplating hasil penelitian adalah: waktu 10 menit, arus 0,4 ampere (rapat arus $0,0305 \mathrm{~A} / \mathrm{cm}^{2}$ ), suhu $40^{\circ} \mathrm{C}$, dan $\mathrm{pH} 3,0$. Kondisi optimum ini memberikan kualitas permukaan lapisan yang baik dengan ciriciri permukaan halus, merata, dan warna lapisan yang cerah.

2. Berdasarkan hasil uji korosi, baja karbon rendah yang telah dilapisi seng ( $\mathrm{Zn}$ ) mempunyai daya tahan yang tinggi terhadap korosi dibandingkan baja karbon rendah tanpa pelapis.

3. Laju korosi baja karbon rendah tanpa pelapis akan meningkat dengan cepat pada waktu setelah 72 jam (selama 3 hari).

\section{Daftar Pustaka}

Achmad, H., 2001. "Elektrokimia \& Kinetika Kimia". PT. Citra Aditya Bakti, Bandung. Halaman $43-105$.

Ahmad, Z.A., 1976. "Pelapisan Nikel pada Non Konduktor secara Pelapisan Listrik dengan Meninjau Efek Rapat Arus dan Waktu Pelapisan terhadap Adhesi". Departemen Kimia, Institut Teknologi Bandung. Halaman 5-46.

Atkins, P.W., 1993. “Kimia Fisika”, Edisi ke-4, Penerjemah: I. Kartohadiprodjo, Erlangga, Jakarta.

Avner, S.M., 1970. “Introduction to Physical Metallurgy”, $2^{\text {nd }}$ Ed, Mc. Graw Hill. Koja Kusta Ltd, Tokyo. Halaman $571-573$.

Bapedal, 1997. “Teknologi Lapis Listrik”. Departemen Kependudukan dan Lingkungan Hidup, Jakarta. Halaman $1-7$.

Companion, A.L., 1991. "Ikatan Kimia", Edisi ke-2, Penerjemah: Dr. Ir. Suminar Achmadi, ITB, Bandung. Halaman $91-99$.

Cotton, F.A., 1989. "Kimia Anorganik Dasar", Penerjemah: S. Suharto, Universitas Indonesia, Jakarta.

Fontana, M.G., 1978. “Corrosion Engineering”, Edisi ke-4, PT. Erlangga, Jakarta. Halaman 97 - 116.

Hartomo, A.J., 1992. “Mengenal Pelapisan Logam (Elektroplating)”, Andi Offset, Jakarta. Halaman 1 - 79.

Kamirudin, 1998. "Penentuan Kondisi Optimum Pelapisan Baja Karbon Rendah Menggunakan Logam Tembaga (Cu) dengan Metode Elektroplating (Skripsi), Universitas Hasanudin, Makassar.

Plindek, V.R., 1977. "Marine Corrosion”, By the MacMillan Press LTd, London and Basingstoke.

Salmon, C.G., 1990."Struktur Baja Desain dan Perilaku”, PT. Gramedia Pustaka Utama, Jakarta. Halaman 44 51.

Smallman, R.E., 1991. “Metalurgi Fisik Modern”, edisi ke-4. PT. Gramedia. Jakarta.

Sumanto, MA, 1996. Pengetahuan Bahan Untuk Mesin dan Listrik., Andi Offset, Yogyakarta. Halaman 10 - 48. Sudjana, 1992. "Metode Statistika”, edisi ke-5, Tarsito, Bandung. Halaman 367-369.

Syukri, 1999. "Kimia Dasar 2", Instititut Teknologi Bandung, Bandung.

Trethewey, K.R., 1991. “Korosi Untuk Mahasiswa Sains dan Rekayasa”. Penerjemah: A. T. Widodo, PT. Gramedia Pustaka Utama, Jakarta. Halaman 25 - 351. 
Uhlig, H.H., 1971. "Corossion and Corossion Control”. John Wiley, New York. Halaman 240 - 248.

Vlack, L.H., 1985. “Elements of Material Science and Engineering”, 5 ${ }^{\text {th }}$ Ed, Addisann - Wesley Publishing Company, USA. Halaman 485 - 511. 